\title{
Rapid Assessment of Habitat Diversity Along the Araras Stream, Brazil
}

\author{
Adriel Barboza Bentos ${ }^{1}$, Anderson de Souza Gallo ${ }^{1}$, \\ Nathalia de França Guimarães ${ }^{1}$, Maicon Douglas Bispo de Souza ${ }^{1}$, \\ Rubismar Stolf ${ }^{2}$, Maria Teresa Mendes Ribeiro Borges ${ }^{3}$
${ }^{1}$ Programa de Pós-graduação em Agroecologia e Desenvolvimento Rural, Universidade Federal de São Carlos - UFSCar, Araras/SP, Brazil
${ }^{2}$ Departamento de Recursos Naturais e Proteção Ambiental, Universidade Federal de São Carlos - UFSCar, Araras/SP, Brazil
${ }^{3}$ Departamento de Tecnologia Agroindustrial e Sócio-Economia Rural, Universidade Federal de São Carlos - UFSCar, Araras/SP, Brazil

\begin{abstract}
Agriculture, urbanization, and industrialization are some of the anthropogenic activities that constantly generate negative impacts on natural environments. Part of this degradation directly affects aquatic systems. This study aimed to evaluate the visual characteristics of the Araras Stream, located in the municipality of Araras, São Paulo state, Brazil. Data was collected at six different assessment sites along the river in both rural and urban areas. The evaluation used a Rapid Habitat Diversity Assessment (RHDA) protocol composed of 22 parameters, which define levels of preservation of ecological conditions. According to this protocol, the $32 \mathrm{Km}$-long study transect along the Araras Stream was rated as impacted (39.6 points). A separate assessment by transects showed that only Transect 1 presented a natural level of preservation (71.8 points). Transects located in the urban area contributed the most to impacts on the aquatic environment. The RHDA protocol proved to be an important tool to evaluate and monitor aquatic environments.
\end{abstract}

Keywords: aquatic ecosystems, riparian vegetation, anthropogenic activities.

\section{INTRODUCTION}

Aquatic ecosystems and the history of water on planet Earth are multifaceted. The close relationship between pollution levels and population density is determined by three main factors: urbanization, industrialization, and large-scale agriculture. Population growth with its consequent urbanization and increase in agricultural areas, reduces the water retention capacity of river basins and the natural capacity to retain pollutants.

In view of the complexity of water use by humans, aquatic ecosystems are the most affected by environmental pollution. Loss of water quality and availability has been observed in several regions and countries due to degradation (Tundisi, 2003).
In the context of aquatic systems, a watershed is a geographic region bounded by water dividers, encompassing the whole catchment area of a waterway. It is a natural geographic unit and its boundaries are established by the flow of water on the surface over time. It is, therefore, the result of the interaction of water with other natural resources (Rocha, 1991).

The micro basin of the Araras Stream is located in the central part of the municipality of Araras, Sao Paulo state, Brazil, and is a good example of anthropogenic actions. The water quality of this stream is affected by different processes of land use and occupation. In addition to mining, deforestation, and pesticide 
use in agricultural areas, intense urban and industrial occupation is observed throughout the basin, which pollutes the stream (Projeto Ecoagri, 2006).

Godoi (2008) highlighted the great importance of characterizing and controlling water quality. In urbanized regions, this control is an essential condition for the evolution and development of populations, either from a socioeconomic perspective or to obtain and maintain quality of life. In rural areas, the importance of monitoring water quality mainly concerns the conservation of ecosystems and the quality of agricultural activities. As a result, methods for rapid qualitative assessment have been developed to describe the holistic quality of the physical habitat of aquatic ecosystems (Hannaford et al., 1997). These methods integrate a set of variables representative of the main components that determine the ecological processes of river systems (Callisto et al., 2002; Rodrigues \& Castro, 2008).

In this sense, the Rapid Habitat Diversity Assessment (RHDA) protocols are introduced, given that they are methodological tools used to evaluate the levels of conservation of environmental conditions in river transects. Therefore, these protocols take into acount the integrated analysis of lotic ecosystems based on the reading of easily understood and quickly applied parameters. Therefore, RHDA protocols are an important tool in environmental monitoring programs (Callisto et al., 2001, 2002; Rodrigues et al., 2008).

The purpose of the present study was to evaluate the environmental degradation processes in rural and urban areas in the longitudinal gradient of the Araras Stream watershed by means of qualitative and quantitative visual analyses using the RHDA protocol. Aiming to contribute to measures that mitigate ecological degradation, this study is expected to identify which stream transects had the greatest negative impact on the aquatic environment.

\section{MATERIAL AND METHODS}

\subsection{Characterization of the study area}

The municipality of Araras is located in the southeast region of Sao Paulo state, Brazil. It occupies an area of $644.8 \mathrm{Km}^{2}$ within the $22^{\circ} 21^{\prime} 25^{\prime \prime} \mathrm{S}$; $47^{\circ} 23^{\prime} 03^{\prime \prime} \mathrm{W}$ geographic coordinates, distant $152 \mathrm{Km}$ from the state capital city. It has a population of 118,000 inhabitants distributed as follows: $6 \%$ in the rural area and 94\% in the urban area (IBGE, 2010).

The regional relief is represented by low rolling hills of sub-plain tops, whose slopes reach $5 \%$ on the sides and $3 \%$ at the top. Towards the north, the topography is more undulating, with slopes of up to $20 \%$. On the flood plains flat areas or depressions with slope $<2 \%$ are generally found. Dystrophic Red Latosol (Oxisol) is predominant in the region; these are strongly acid, ancient soils at an advanced stage of weathering, with low base saturation (Resende et al., 2007; Santos, 2006).

Climate in the region is Cwa according to Köppen classification, mesothermal, with hot summers, and dry winters with mean lowest and highest temperatures of $18^{\circ} \mathrm{C}$ and $22^{\circ} \mathrm{C}$, respectively. The dry season is from April to September, with total rainfall in the driest month $<30 \mathrm{~mm}$. Most rainfall occurs in January or February (Magini \& Chagas, 2003).

The Araras Stream micro basin is composed of other streams that flow west to east-northeast, and has its boundaries within the municipality (IBGE 1:50.000, Folha Araras-SF23YAII). The micro basin covers an area of approximately $400 \mathrm{Km}^{2}$, being the main source of the Tambury Dam, which provides $15 \%$ of the water supply of the municipality and, according to Magini \& Chagas (2003), presents a dendritic pattern similar to tree branches.

\subsection{Field procedures and data analysis}

The choice of the studied transects was based on the criteria of ease of access and spatial distribution. Thus these transects were established upstream from the longitudinal gradient of Araras Stream comprising rural (Transects 1,2, and 6) and urban (Transects 3, 4, and 5) areas, according to the mosaic shown in Figure 1.

The extension analyzed included a longitudinal gradient of approximately $32 \mathrm{Km}$ and, as presented in Table 1, some basic characteristics observed are listed for each sampled transect.

The visual analysis was conducted according to the RHDA protocol. This protocol developed by Callisto et al. (2002) is composed of two parts: the first part, adapted from the Ohio Environmental Protection Agency, USA (EPA, 1987), seeks to evaluate the characteristics of the transect and the environmental impacts caused 


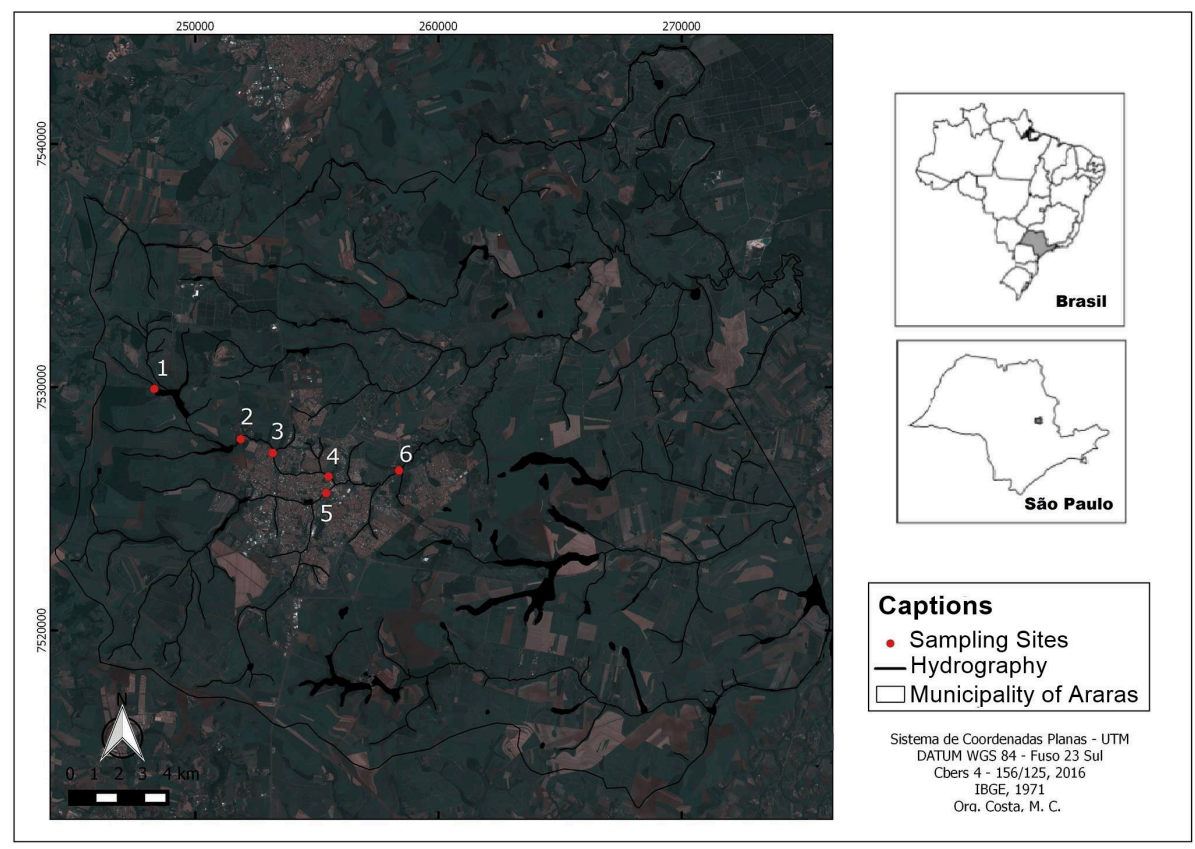

Figure 1. Mosaic of the municipality of Araras and the six transects established for microbiology evaluation along the Araras Stream. Municipality of Araras, São Paulo state, Brazil.

Table 1. Primary characteristics observed at the studied transects (geographic coordinates, altitude, soil use and occupation in the surrounding environment). Municipality of Araras, São Paulo state, Brazil.

\begin{tabular}{|c|c|c|c|c|}
\hline $\begin{array}{l}\text { Sampled } \\
\text { transects }\end{array}$ & $\begin{array}{l}\text { Geographic } \\
\text { coordinates }\end{array}$ & Altitude & $\begin{array}{l}\text { Characteristics of } \\
\text { transects }\end{array}$ & $\begin{array}{l}\text { Soil use and occupation in the } \\
\text { surrounding environment }\end{array}$ \\
\hline 1 & $\begin{array}{l}22^{\circ} 19^{\prime} 00.45^{\prime \prime} \mathrm{S} \\
47^{\circ} 26^{\prime} 29.64^{\prime \prime} \mathrm{W}\end{array}$ & 655 masl & Near the source. & $\begin{array}{l}\text { Preserved riparian vegetation, but } \\
\text { surrounded by areas cultivated with } \\
\text { sugarcane. }\end{array}$ \\
\hline 2 & $\begin{array}{l}22^{\circ} 20^{\prime} 12.49^{\prime \prime} \mathrm{S} \\
47^{\circ} 24^{\prime} 32.10^{\prime \prime} \mathrm{W}\end{array}$ & 631 masl & Santa Lúcia Dam. & $\begin{array}{l}\text { Água Bruta - Tambury Lift Station. } \\
\text { Legal reserve of planted eucalyptus } \\
\text { on one of the banks. }\end{array}$ \\
\hline 3 & $\begin{array}{l}22^{\circ} 20^{\prime} 31.56^{\prime \prime} \mathrm{S} \\
47^{\circ} 23^{\prime} 46.41^{\prime \prime} \mathrm{W}\end{array}$ & 620 masl & $\begin{array}{l}\text { Beginning of the urban } \\
\text { area. }\end{array}$ & $\begin{array}{l}\text { Reforested riparian forest. One of } \\
\text { the banks with vegetation less than } \\
30 \text { m wide. }\end{array}$ \\
\hline 4 & $\begin{array}{l}22^{\circ} 21^{\prime} 16.54 ” \mathrm{~S} \\
47^{\circ} 22^{\prime} 12.89^{\prime \prime} \mathrm{W}\end{array}$ & 607 masl & $\begin{array}{l}\text { Before the junction } \\
\text { with Furnas Stream. }\end{array}$ & Channeled area. \\
\hline 5 & $\begin{array}{l}22^{\circ} 21^{\prime} 28.32^{\prime \prime} \mathrm{S} \\
47^{\circ} 22^{\prime} 58.61^{\prime \prime} \mathrm{W}\end{array}$ & 606 masl & $\begin{array}{l}\text { Together with the } \\
\text { Furnas Stream. }\end{array}$ & Channeled area. \\
\hline 6 & $\begin{array}{l}22^{\circ} 20^{\prime} 57.85^{\prime \prime} \mathrm{S} \\
47^{\circ} 20^{\prime} 45.46^{\prime \prime} \mathrm{W}\end{array}$ & 601 masl & $\begin{array}{l}\text { Viaduct over the } \\
\text { railway (rural area). }\end{array}$ & $\begin{array}{l}\text { Grassland. Depleted riparian } \\
\text { vegetation, intense occupation with } \\
\text { Leucaena leucocephala }\end{array}$ \\
\hline
\end{tabular}

Caption: masl = meters above sea level.

by anthropogenic activities (Table 2); the second part, adapted from Hannaford et al. (1997), determines the parameters to assess the habitat and conservation levels of the natural conditions (Table 3 ).

The method is based on the quantification of 22 parameters and the final score is obtained from the sum of the values assigned to each parameter independently. The extreme values for the scoring of the RHDA procedure range from 0 (advanced state of degradation) to 100 points (pristine conditions or no degradation). The final scores reflect the level of environmental integrity or preservation of the global 
Table 2. RHDA parameters developed by Callisto et al. (2002), adapted from the Ohio Environmental Protection Agency, Ohio, USA (EPA, 1987).

\begin{tabular}{|c|c|c|c|}
\hline \multirow{2}{*}{ Parameters } & \multicolumn{3}{|c|}{ Scores } \\
\hline & 4 points & 2 points & 0 points \\
\hline $\begin{array}{l}\text { 1. Type of occupation on the banks of } \\
\text { the water body }\end{array}$ & Natural vegetation & $\begin{array}{l}\text { Grassland / Agriculture } \\
\text { / Monoculture / Refor- } \\
\text { estation }\end{array}$ & $\begin{array}{l}\text { Residential / Commercial } \\
\text { / Industrial }\end{array}$ \\
\hline $\begin{array}{l}\text { 2. Erosion close to and/or on the stream } \\
\text { banks and silting in stream bed }\end{array}$ & Absent & Moderate & Severe \\
\hline 3. Anthropogenic changes & Absent & $\begin{array}{l}\text { Changes of domestic } \\
\text { origin (sewage; garbage) }\end{array}$ & $\begin{array}{l}\text { Changes of industrial/ } \\
\text { urban origin (factories; } \\
\text { channeling) }\end{array}$ \\
\hline 4. Vegetation cover in the stream bed & Partial & Total & Absent \\
\hline 5. Water odor & None & Sewage (rotten egg) & Oil \\
\hline 6. Water oiliness & Absent & Moderate & Abundant \\
\hline 7. Water transparency & Transparent & Turbid (strong tea) & Dull or colored \\
\hline 8. Sediment odor (stream bed) & None & Sewage (rotten egg) & Oil \\
\hline 9. Stream bed oiliness & Absent & Moderate & Abundant \\
\hline 10. Embeddedness & Stones/gravel & Fine sediment/sand & Cement/channeled \\
\hline
\end{tabular}

Table 3. RHDA parameters developed by Callisto et al. (2002), adapted from Hannaford et al. (1997).

\begin{tabular}{|c|c|c|c|c|}
\hline \multirow{2}{*}{ Parameters } & \multicolumn{4}{|c|}{ Score } \\
\hline & 5 points & 3 points & 2 points & 0 points \\
\hline
\end{tabular}

Greater than 50\% mix of diversified habitat:

11. Instream presence of snags, cover submersed trunks, rubble, or others.

Well-developed riffle

12. Epifaunal and run; riffle as wide as substrate the stream and length extends twice the width of stream.

Relatively frequent occurrence of riffles;

13. Frequency distance between riffles of riffles divided by the width of the stream is between 5 and 7 .

\section{0 to $50 \%$ mix of} diversified habitat: adequate for maintenance of populations of aquatic organisms.

Riffle as wide as the stream, but length is less than twice the width of stream.

Infrequent occurrence of riffles; distance between riffles divided by the width of the stream is between 7 and 15 .

\begin{tabular}{|c|c|}
\hline $\begin{array}{l}\text { 14. Types of } \\
\text { substrate }\end{array}$ & $\begin{array}{l}\text { Pebbles are abundant } \\
\text { mainly in the sources. }\end{array}$ \\
\hline $\begin{array}{l}\text { 15. Fine } \\
\text { sediment } \\
\text { deposition }\end{array}$ & $\begin{array}{l}\text { Up to } 25 \% \text { of the } \\
\text { bottom covered with } \\
\text { fine sediment. }\end{array}$ \\
\hline $\begin{array}{l}\text { 16. Sediment } \\
\text { deposition }\end{array}$ & $\begin{array}{l}\text { Less than } 5 \% \text { of the } \\
\text { bottom affected by } \\
\text { sediment deposition; no } \\
\text { deposition in pools. }\end{array}$ \\
\hline
\end{tabular}

Abundance of pebbles; common gravel.

Between 25 and $50 \%$ of the bottom covered with fine sediment.

Some evidence of modification of the bed mostly from increase of gravel, sand, or fine sediment; 5 to $30 \%$ of the bed affected; slight deposition in pools.
10 to $30 \%$ mix of diversified habitat: habitat availability less than adequate.

Run may be lacking; riffle not as wide as the stream and length is less than twice the width of stream.

Occasional riffles; habitats formed by stream bed contours; distance between riffles divided by the width of the stream is between 15 and 25 .

Stream bed consisting predominantly of Stony, with pebbles, or gravel; presence of some loamy stream bed. pebbles.

Between 50 and $75 \%$ of Over $75 \%$ of the bottom the bottom covered with covered with fine fine sediment.

Moderate deposition of gravel, sand, or fine sediment on the banks; 30 to $50 \%$ of the stream bed affected; moderate deposition in pools prevalent.
Less than $10 \%$ mix of diversified habitat: lack of habitat is obvious.

Nonexistent riffles or runs.

Generally flat water or shallow riffles; poor habitat; distance between riffles divided by the width of the stream is a ratio of $>25$. sediment.

Heavy deposits of fine material; increased development of the banks; over $50 \%$ of the bottom modified; pools almost absent owing to substantial sediment deposition. 
Table 3. Continue...

\begin{tabular}{|c|c|c|c|c|}
\hline \multirow{2}{*}{ Parameters } & \multicolumn{4}{|c|}{ Score } \\
\hline & 5 points & 3 points & 2 points & 0 points \\
\hline $\begin{array}{l}\text { 17. Channel } \\
\text { alteration }\end{array}$ & $\begin{array}{l}\text { Channeling } \\
\text { (rectification) or } \\
\text { dredging absent or } \\
\text { minimal; stream with } \\
\text { normal pattern. }\end{array}$ & $\begin{array}{l}\text { Some channeling } \\
\text { present, usually in areas } \\
\text { of bridge abutments; } \\
\text { evidence of channeling } \\
\text { greater than past } 20 \\
\text { years. }\end{array}$ & $\begin{array}{l}\text { New embankments } \\
\text { present on both banks; } \\
40 \text { to } 80 \% \text { of stream } \\
\text { reach modified. }\end{array}$ & $\begin{array}{l}\text { Banks modified; over } \\
80 \% \text { of stream reach } \\
\text { modified. }\end{array}$ \\
\hline $\begin{array}{l}\text { 18. Channel } \\
\text { flow status }\end{array}$ & $\begin{array}{l}\text { Water reaches base } \\
\text { of both lower banks; } \\
\text { minimal amount of } \\
\text { channel substrate is } \\
\text { exposed. }\end{array}$ & $\begin{array}{l}\text { Water fills more than } \\
75 \% \text { of the available } \\
\text { channel; or less than } \\
25 \% \text { of channel } \\
\text { substrate is exposed. }\end{array}$ & $\begin{array}{l}\text { Water fills } 25 \text { to } 75 \% \text { of } \\
\text { the available channel, } \\
\text { and/or riffle substrates } \\
\text { are mostly exposed. }\end{array}$ & $\begin{array}{l}\text { Very little water in } \\
\text { channel and mostly } \\
\text { present as standing } \\
\text { pools. }\end{array}$ \\
\hline $\begin{array}{l}\text { 19. Bank } \\
\text { vegetative } \\
\text { protection }\end{array}$ & $\begin{array}{l}\text { More than } 90 \% \text { of } \\
\text { stream bank surfaces } \\
\text { covered with native } \\
\text { riparian vegetation, } \\
\text { including trees, } \\
\text { understory shrubs, } \\
\text { and non-woody } \\
\text { macrophytes; minimal } \\
\text { evidence of disruption; } \\
\text { all plants allowed to } \\
\text { grow normally. }\end{array}$ & $\begin{array}{l}70 \text { to } 90 \% \text { of stream } \\
\text { bank surfaces covered } \\
\text { with native riparian } \\
\text { vegetation; evident } \\
\text { disruption but not } \\
\text { affecting full plant } \\
\text { growth potential to any } \\
\text { great extent. }\end{array}$ & $\begin{array}{l}50 \text { to } 70 \% \text { of stream } \\
\text { bank surfaces covered } \\
\text { with native riparian } \\
\text { vegetation; obvious } \\
\text { disruption; patches of } \\
\text { bare soil; less than one } \\
\text { half of the potential } \\
\text { plant stubble height } \\
\text { remaining. }\end{array}$ & $\begin{array}{l}\text { Less than } 50 \% \text { of stream } \\
\text { bank surfaces covered } \\
\text { with native riparian } \\
\text { vegetation; very high } \\
\text { disruption of stream } \\
\text { bank vegetation. }\end{array}$ \\
\hline $\begin{array}{l}\text { 20. Bank } \\
\text { stability }\end{array}$ & $\begin{array}{l}\text { Stable banks; absent or } \\
\text { minimal evidence of } \\
\text { erosion; little potential } \\
\text { for future problems; } \\
\text { less than } 5 \% \text { of bank } \\
\text { affected. }\end{array}$ & $\begin{array}{l}\text { Moderately stable } \\
\text { banks; small eroded } \\
\text { areas frequent; } 5 \text { to } \\
30 \% \text { of bank in reach } \\
\text { presents areas of } \\
\text { erosion. }\end{array}$ & $\begin{array}{l}\text { Moderately unstable } \\
\text { banks; } 30 \text { to } 60 \% \text { of } \\
\text { bank in reach presents } \\
\text { eroded areas; high } \\
\text { erosion potential during } \\
\text { floods. }\end{array}$ & $\begin{array}{l}\text { Unstable banks; many } \\
\text { eroded areas; frequent } \\
\text { uncovered areas on } \\
\text { stream bends; } 60 \text { to } \\
100 \% \text { of banks present } \\
\text { erosional scars. }\end{array}$ \\
\hline $\begin{array}{l}\text { 21. Riparian } \\
\text { vegetative } \\
\text { zone width }\end{array}$ & $\begin{array}{l}\text { Width of riparian zone } \\
>18 \mathrm{~m} \text {; absence of } \\
\text { anthropogenic activities } \\
\text { (farming, roads, etc.) }\end{array}$ & $\begin{array}{l}\text { Width of riparian zone } \\
\text { between } 12 \text { and } 18 \\
\text { minimal anthropogenic } \\
\text { influence. }\end{array}$ & $\begin{array}{l}\text { Width of riparian zone } \\
\text { between } 6 \text { and } 12 \mathrm{~m} \text {; } \\
\text { intense anthropogenic } \\
\text { influence. }\end{array}$ & $\begin{array}{l}\text { Width of riparian zone } \\
\text { between }<6 \mathrm{~m} \text {; little or } \\
\text { no riparian vegetation } \\
\text { due to anthropogenic } \\
\text { activities. }\end{array}$ \\
\hline $\begin{array}{l}\text { 22. Presence } \\
\text { of aquatic } \\
\text { plants }\end{array}$ & $\begin{array}{l}\text { Small aquatic } \\
\text { macrophytes and/ } \\
\text { or mosses distributed } \\
\text { along the stream bed. }\end{array}$ & $\begin{array}{l}\text { Aquatic macrophytes, } \\
\text { or filamentous algae, } \\
\text { or mosses distributed } \\
\text { along the stream } \\
\text { bed; substrate with } \\
\text { periphyton. }\end{array}$ & $\begin{array}{l}\text { Filamentous algae or } \\
\text { macrophytes on few } \\
\text { rocks or in some pools; } \\
\text { biofilm and abundant } \\
\text { periphyton. }\end{array}$ & $\begin{array}{l}\text { Absence of aquatic } \\
\text { vegetation in the stream } \\
\text { bed or large macrophyte } \\
\text { formations, e.g., water } \\
\text { hyacinth. }\end{array}$ \\
\hline
\end{tabular}

situation found in the transects of basins under investigation (Rodrigues \& Castro, 2008).

Assessment of the Araras Stream was conducted in December 2014. In each transect of the stream, the RHDA protocol was applied by four previously trained observers. Data was statistically analyzed using the Tukey test at 5\% significance level $(p<0.05)$ for intra-observer variation. For the scores from the RHDA protocol, arithmetical means were calculated and the parameters that presented scores $\leq 2$ in Table 1 and $\leq 2.5$ in Table 2 were classified as critical points (Carvalho et al., 2014).

The results were compared to a reference condition which presented the best habitat aspects listed in the protocol. After being graphically expressed, the results were classified according to the methodology by Callisto et al. (2002), which defines three levels of preservation: the range of 0 to 40 points indicates impacted transects; from 40 to 60 points indicates altered transects, and above 60 points indicates natural transects. 


\section{RESULTS AND DISCUSSION}

Application of the RHDA protocol in the Araras Stream micro basin showed a mean final score of 39.6 points, classifying the longitudinal transect evaluated as impacted (Figure 2). This situation verified by the protocol emphasizes the critical state of the natural environmental conditions of this stream (Figure 2). Plafkin et al. (1989) reports that the results are based on values obtained from minimally disturbed sites, considered as a reference, and which are based on the premise that anthropogenically unaffected watercourses exhibit more favorable environmental conditions (Minatti-Ferreira \& Beaumord, 2004).

Associated with the presence of animals, branches, trunks, pebbles, stones, and other stable forms of habitat along the stream, the parameter Types of Substrate (14) obtained a general mean score below one (1). Therefore, it was defined as a critical point, considering the observations related to the scarcity and/or absence of substrata, with monotonous habitats or habitats with little diversity.

In this case, based only on the previously mentioned circumstance, it is possible to conceive the negative environmental conditions found in the water body, because according to Callisto et al. (2002), water courses with diversity of habitats are fundamental for the maintenance of aquatic organisms. However, when substrates are frequently altered, the possibility of finding healthy habitats decreases.
Directly associated with the aforementioned parameter, geomorphological parameters such as Fine Sediment Deposition (15) and Sediment Deposition (16) also presented low mean scores and were defined as critical points. These mean scores resulted from the observation of several disturbed areas, erosive processes, landslides and exposed roots and soils, among other conditions, which constantly contribute to the accumulation of fine sediment on the stream bed; except where the stream presented no channeled banks or cemented bottom (Transects 4 and 5).

Bank Vegetative Protection (19) was the parameter with the lowest mean score, with less than $50 \%$ of the native riparian vegetation present. This condition was evident in almost all assessed transects, except for Transect 1. Moderate disturbance was observed in the upstream transects (Transects 1 and 2), but the situation worsens further downstream (transects located in the urban area) as a consequence of land use and occupation processes on the Stream banks.

Anthropogenic disturbances in the surroundings of watercourses, such as those observed in this study, often occur in several regions of the country, and have been reported in many studies that showed changes in riparian vegetation, such as those by Magini \& Chagas (2003), Minatti-Ferreira \& Beaumord (2004), Rodrigues et al. (2008), and Carvalho et al. (2014).

It is worth noting that this situation indicates a need to restore and preserve the environment because, according to Vogel et al. (2009), the riparian ecosystem

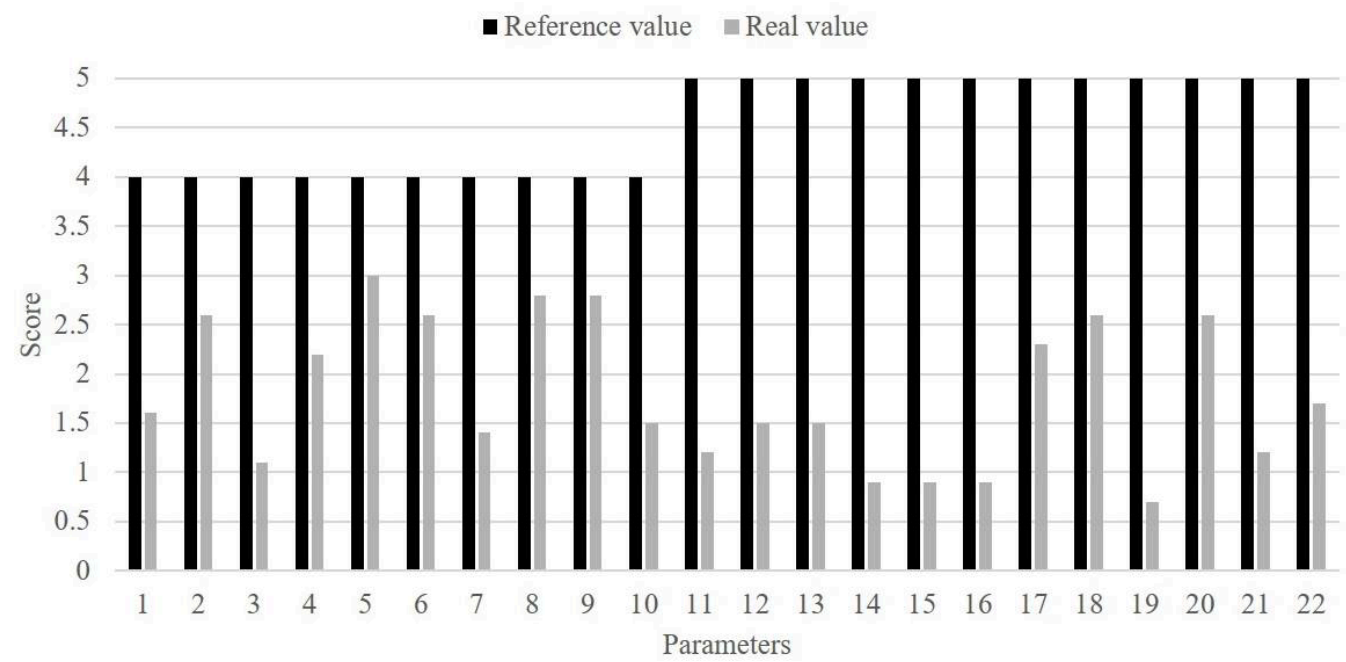

Figure 2. Mean score for the Araras Stream catchment area compared with that of a reference lotic environment. 
plays an important role in functions associated with the generation of direct flow in watersheds, thus contributing to increased water storage capacity, maintenance of water quality in the basin, and water retention by the plant root system and nutrients released from terrestrial ecosystems. In addition, it provides bank stability, thermal water balance, and formation of ecological corridors.

Figure 3 shows the scores by sampled transect separately. Overall, the results presented different classifications, considering that only Transect 1 (71.8 points) was classified as of natural conservation level. This occurred given that this transect is located in a private property in the rural area, near the stream source. This transect also maintains essential ecological characteristics, such as banks vegetated with native tree species extending over $30 \mathrm{~m}$ wide, with a diversity of plant species at different stages of succession, significant contribution of litter, presence of small fish, and mild microclimate.

In contrast, Transects 2 (40.5 points) and 6 ( 43.8 points) were classified as altered. However, the impacted transects with the most acute conditions were Transects 3,4 , and 5 (scores of 32.3, 28.3, and 27.8 points, respectively).

The graph results indicated a parabola (Figure 3). Thus the transects located within the rural perimeter (Transects 1,2 and 6) presented the highest mean scores, and consequently the best environmental conditions; as the stream flows through the urban areas, the scores decrease (Transects 3, 4 and 5).
Processes of disordered land use and occupation are associated with these characteristics. However, the factors that contributed to Transects 3, 4, and 5 being classified as affected were occupation of the stream banks by residences, businesses, and industry; modifications such as rectification and channeling; stream bottom with fine sediment and sediment deposits; and the consequent lower habitat heterogeneity and absence of riparian vegetation, among other observations. These are described in the following according to the separate analyses of parameters.

Analyzing the parameters separately, as illustrated in Figure 4, it was possible to identify the critical factors. However, in Transect 3 (Figure 4c), it is worth noting the parameters that obtained the highest mean scores: Vegetation Cover on the Stream Bed (4) and Presence of Aquatic Plants (22). These parameters obtained the highest scores among the sampled transects owing to the significant amounts of macrophytes, mosses, and substrate with periphyton observed at the sites. The parameters Water Odor (6) and Water Oiliness (9) presented scores equal to or higher than those of the established critical level.

In transect 4, represented in Figure 4d, the parameters that obtained the lowest scores were Substrate Types (14) - with the stream bed characterized as loamy, and Fine Sediment Deposition (15) - with more than $75 \%$ of the stream bed covered with fine sediment. According to Rodrigues et al. (2010), this is a negative factor because the presence of sediments is directly related

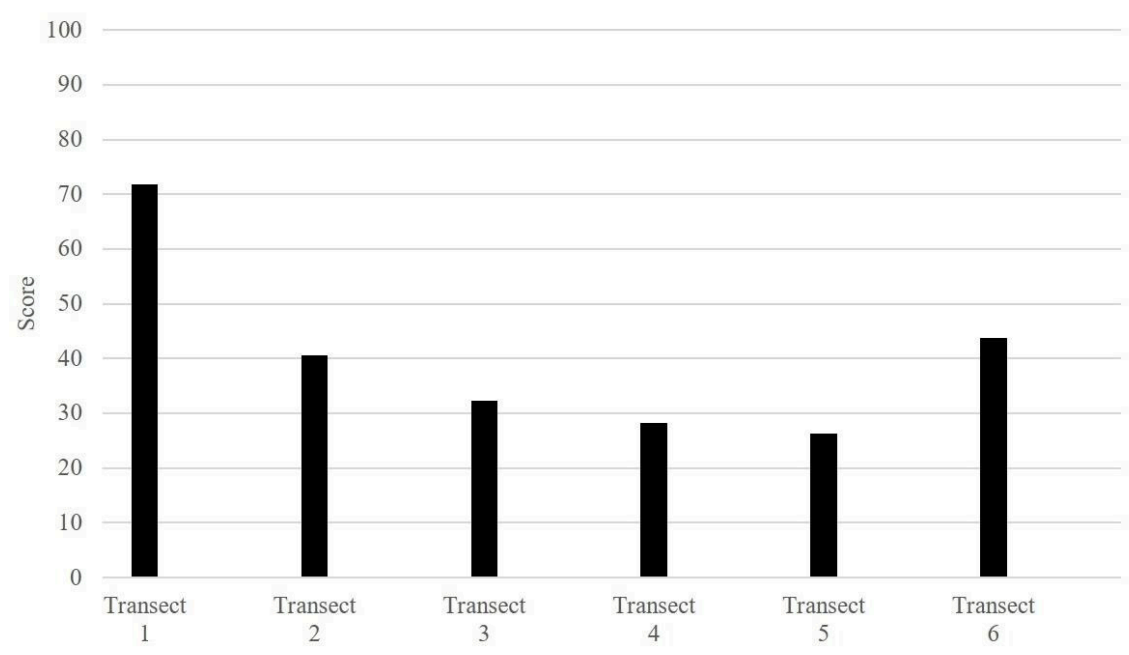

Figure 3. Mean values of sampled transects. 
a)

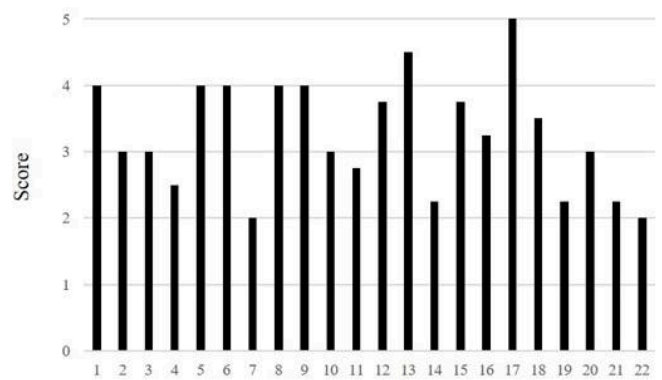

Parameters

c)

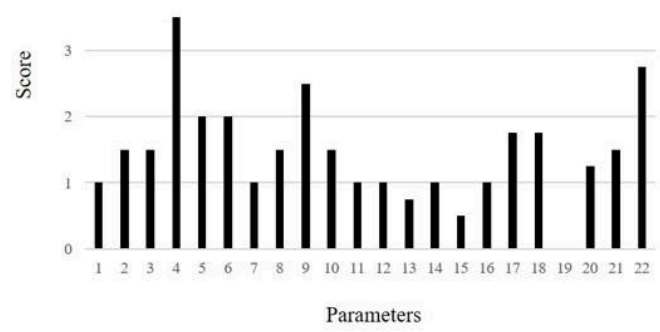

e)

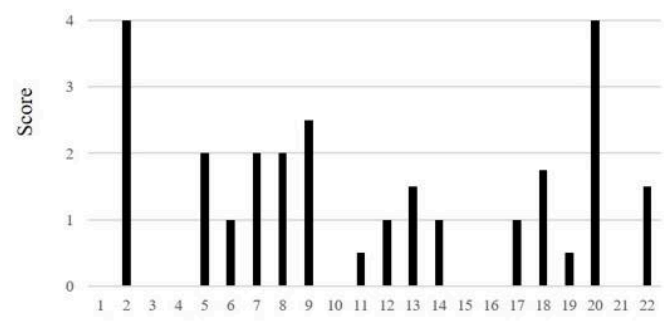

Parameters b)

Transect 2

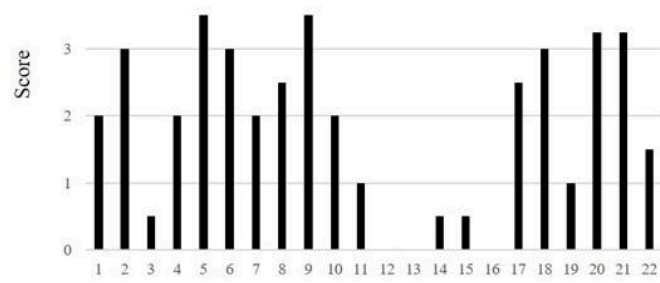

Parameters

d)

Transect 4

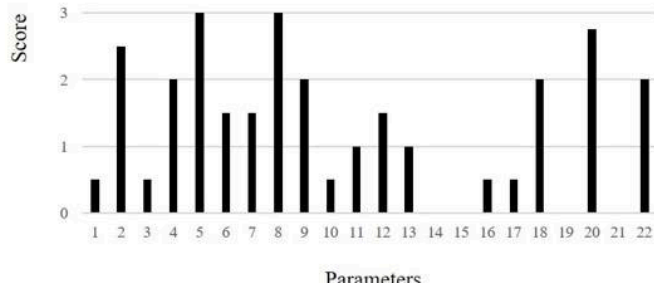

f)

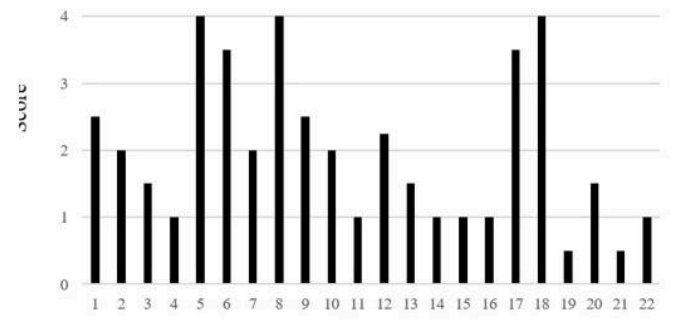

Parameters

Figure 4. Mean values of each parameter at each transect evaluated. Transect 1 (a); transect 2 (b); transect 3 (c); transect 4 (d); transect 5 (e) and; transect 6 (f).

to the quality of the aquatic habitat. However, when these sediments are deposited, forming gutters or obstructing the stream bed, they reduce the number of sites available for aquatic biota.

In spite of being considered Permanent Preservation Areas (PPA) by the Brazilian Forest Code (Brasil, 2012), the strip of land occupied by the Riparian Forest of the Araras Stream along Transect 4 is reduced due to construction for human habitation, deforestation for open agricultural areas, fields cultivated with sugarcane, pasture areas, and agricultural activities in general. According to Dellamatrice \& Monteiro (2014), activities aimed at increasing the production of agricultural goods are of high impact, mainly due to the loss of biodiversity and quality of water resources.

Transect 5, located along another stream (Furnas Stream), was chosen to complement the evaluation because of its importance as a water source for the municipality of Araras. It is also worth mentioning that, as stated in the National Guide for the Collection 
Table 4. RHDA protocol general rating by observer at each sampled transect (from Transects 1 to 6). Result comparison of four observers by the Turkey test at 5\% probability, mean, and standard deviation.

\begin{tabular}{|c|c|c|c|c|c|c|c|c|}
\hline \multirow{2}{*}{$\begin{array}{l}\text { Treatments } \\
\text { (Observers) }\end{array}$} & \multicolumn{6}{|c|}{ Blocks (TRANSECTS) } & \multirow[b]{2}{*}{$\begin{array}{c}\text { Treatment } \\
\text { mean }\end{array}$} & \\
\hline & $\begin{array}{c}\text { Transect } \\
1\end{array}$ & $\begin{array}{c}\text { Transect } \\
2\end{array}$ & $\begin{array}{c}\text { Transect } \\
3\end{array}$ & $\begin{array}{c}\text { Transect } \\
4\end{array}$ & $\begin{array}{c}\text { Transect } \\
5\end{array}$ & $\begin{array}{c}\text { Transect } \\
6\end{array}$ & & \\
\hline Observer 1 & 64 & 46 & 43 & 22 & 37 & 20 & 44.5 & A \\
\hline Observer 2 & 74 & 39 & 20 & 41 & 67 & 26 & 42.0 & A \\
\hline Observer 3 & 76 & 45 & 26 & 32 & 40 & 33 & 38.7 & A \\
\hline Observer 4 & 73 & 32 & 42 & 18 & 31 & 31 & 37.8 & A \\
\hline Mean/blocks & 71.75 & 40.50 & 32.75 & 28.25 & 43.75 & 27.50 & 40.75 & \\
\hline Standard deviation & 4.60 & 5.59 & 9.98 & 8.95 & 13.81 & 5.02 & 2.67 & \\
\hline
\end{tabular}

Means with the same letters do not differ statistically by the Tukey test at $5 \%$ significance level.

and Preservation of Samples of CETESB (2011), it is necessary to include any possible areas that can influence the sampling of the water body. This transect presented the most critical environment according to the application of the RHDA protocol (Figure 4e). Characteristics predominant in urbanized areas were observed, such as nearby factories and industries, absence of riparian vegetation, and channeling of the banks. According to Palmer et al. (2005), the latter constitutes a problem because the rectification and channeling of rivers has as a direct consequence the reduction of the catchment area of river basins, causing a drastic decrease in the density and diversity of aquatic species.

Furthermore, the observation of greatest relevance gained through the application of the RHDA protocol was that the transects classified as affected (Transects 3, 4, and 5) are located in the urban area. This aspect reveals a greater negative influence of this land use on the watercourse. A similar situation was reported by Magini \& Chagas (2003) when studying the same stream. There, they verified that the urban occupation of the banks and industrial activities were the main factors of impact.

Table 4 shows a comparison between the scores of each observer for the present study, confirming the low variation between assessments. It is worth mentioning that the observers who participated in this study had already conducted previous evaluations using the same tool. According to Rodrigues \& Castro (2008), this increases the accuracy of the method.

The specific scientific literature has shown that, in general, assessment protocols present a common origin and have improved over time. Therefore, the protocols have developed consistent variables for the environmental analysis of watercourse banks because they reflect what many researchers have considered important for impact assessment over the past decades.

Professional observers who begin to use rapid assessment protocols can focus on everything that this field of research has highlighted so far. Therefore, the method has a didactic function, as underlined by Callisto et al. (2002). Moreover, from the standpoint of the layperson, it is possible to acquire this clear and useful understanding, thereby justifying the advances in the use of the RHDA protocol.

\section{CONCLUSIONS}

Application of the RHDA protocol along part of the Araras Stream revealed a condition of concern with respect to the state of conservation of the lotic environment. The longitudinal transect sampled was classified as impacted and presented the following aggravating characteristics: occupation of the banks, presence of channeling and rectification, acute disruption of the riparian forest, cemented or loamy stream bed, impoverished habitat, absence of aquatic fauna, and erosive processes causing sedimentation of the stream bed.

The separate assessment of the transects identified the best environmental quality in a private property in the rural area, near the spring region. It also revealed that the regions most impacted by anthropogenic activities are located within the urban perimeter.

Application of the RHDA protocol in the micro basin of the Araras Stream proved to be simple, inexpensive, and capable of providing a holistic assessment of the aquatic ecosystem, presenting data that can be used in decision making for the management and conservation of water resources. 


\section{SUBMISSION STATUS}

Received: 4 feb., 2016

Accepted: 18 apr., 2017

\section{CORRESPONDENCE TO}

\section{Adriel Barboza Bentos}

Programa de Pós-graduação em Agroecologia e Desenvolvimento Rural, Universidade Federal de São Carlos - UFSCar, Rodovia Anhanguera, Km 174, SP-330, CEP 13600-970, Araras, SP, Brazil e-mail: adriel_bb@hotmail.com

\section{REFERENCES}

Brasil. Lei $n^{\circ}$ 12.651, 25 de maio de 2012. Dispõe sobre a proteção da vegetação nativa e dá outras providências. Diário Oficial da República Federativa do Brasil, Brasília, DF (2012 may).

Callisto M, Ferreira WR, Moreno P, Goulart M, Petrucio M. Aplicação de um protocolo de avaliação rápida da diversidade de habitats em atividades de ensino e pesquisa (MG-RJ). Acta Limnologica Brasiliensia 2002; 14(1): 91-98.

Callisto M, Goulart M, Moretti M. Macroinvertebrados Bentônicos como Ferramenta para Avaliar a Saúde de Riachos. Revista Brasileira de Recursos Hídricos 2001; 6(1): 71-82. http://dx.doi.org/10.21168/rbrh.v6n1.p71-82.

Carvalho EM, Bentos AB, Pereira NS. Avaliação rápida da diversidade de habitats em um ambiente lótico. Interbio 2014; 8(1): 45-55.

Companhia Ambiental do Estado de São Paulo - CETESB. Guia nacional de coleta e preservação de amostras: água, sedimento, comunidades aquáticas e efluentes líquidos. São Paulo: CETESB; 2011.

Dellamatrice PM, Monteiro RTR. Principais aspectos da poluição de rios brasileiros por pesticidas. Revista Brasileira de Engenharia Agrícola e Ambiental 2014; 18(12): 1296-1301. http://dx.doi.org/10.1590/1807-1929/ agriambi.v18n12p1296-1301.

Environmental Protection Agency - EPA. Biological criteria for the protection of aquatic life. Columbus: Division of Water Quality, Planning and Assessment, Surface Water Section; 1987.

Godoi EL. Monitoramento de água superficial densamente poluída: o Córrego Pirajuãra, região metropolitana de São Paulo, Brasil [dissertation]. São Paulo: Instituto de Pesquisas Energéticas e Nucleares; 2008.

Hannaford MJ, Barbour MT, Resh VH. Training reduces observer variability in visual-based assessments of stream habitat. Journal of the North American Benthological Society 1997; 16(4): 853-860. http://dx.doi.org/10.2307/1468176.

Instituto Brasileiro de Geografia e Estatística - IBGE. Censo Demográfico 2010 [online]. Rio de Janeiro: IBGE; 2010. [cited 2015 July 18]. Available from: www.cidades. ibge.gov.br/xtras/perfil.php?.codmun=350330

Magini C, Chagas RL. Microzoneamento e diagnóstico físico-químico do Ribeirão das Araras, SP. Geociências 2003; 22(2): 195-208.

Minatti-Ferreira DD, Beaumord AC. Avaliação rápida de integridade ambiental das sub-bacias do rio Itajaí-Mirim no Município de Brusque, SC. Revista Saúde \& Ambiente 2004; 5(2): 21-27.

Palmer MA, Bernhardt ES, Allan JD, Lake PS, Alexander $\mathrm{G}$, Brooks $\mathrm{S}$ et al. Standards for ecologically successful river restoration. Journal of Applied Ecology 2005; 42(2): 208217. http://dx.doi.org/10.1111/j.1365-2664.2005.01004.x.

Plafkin JL, Barbour MT, Porter KD, Gross SK, Hughes RM. Rapid bioassessment protocols for use in streams and rivers: benthic macroinvertebrates and fish. Washington: EPA; 1989.

Projeto Ecoagri. Diagnóstico ambiental da agricultura em São Paulo: bases para um desenvolvimento rural sustentável. Campinas: FAPESP; 2006. Relatório III.

Resende M, Curi N, Rezende SB, Correa GF. Pedologia: base para distinção de ambientes. 5th ed. Lavras: Editora UFLA; 2007.

Rocha JSM. Manual de manejo integrado de bacias hidrográficas. Santa Maria: Universidade Federal de Santa Maria; 1991.

Rodrigues ASL, Castro PTA. Protocolos de avaliação rápida: instrumentos complementares no monitoramento dos recursos hídricos. Revista Brasileira de Recursos Hídricos 2008; 13(1): 161-170. http://dx.doi.org/10.21168/rbrh. v13n1.p161-170.

Rodrigues ASL, Malafaia G, Castro PTA. Avaliação ambiental de trechos de rios na região de Ouro Preto-MG através de um protocolo de avaliação rápida. Revista de Estudos Ambientais 2008; 10(1): 74-83.

Rodrigues ASL, Malafaia G, Castro PTA. A importância da avaliação do habitat no monitoramento da qualidade dos recursos hídricos: uma revisão. SaBios: Revista de Saúde e Biologia 2010; 5(1): 26-42.

Santos HG. Sistema brasileiro de classificação de solos. 2nd ed. Rio de Janeiro: Embrapa Solos; 2006.

Tundisi JG. Água no século XXI: enfrentando a escassez. 2rd ed. São Carlos: Rima; 2003.

Vogel HF, Zawadzki CH, Metri R. Florestas ripárias: importância e principais ameaças. Sabios: Revista Saúde e Biologia 2009; 4(1): 24-30. 